\title{
Extramedullary plasmacytoma presenting as a mediastinal mass
}

\author{
Mediastende kitle ile beliren ilik dışı (ekstramedüller) plazmositom
}

\author{
Arpana Shukla, Vivek Bansal, Ritu Bhutani, Gaurav Kumar, Jai Sharma, Surinder Solanki, \\ Anurag Mehta \\ Rajiv Gandhi Cancer Institute and Research Centre, Department of Radiation Oncology, Sector V, Rohini, Delhi, India
}

\begin{abstract}
Extramedullary plasmacytoma (EMP) is a plasma cell neoplasm without bone marrow involvement or other systemic characteristics of multiple myeloma. Few large-scale clinical studies have been conducted because of the rarity of EMP, especially when it arises from the mediastinum. Herein we report a rare case of solitary mediastinal plasmacytoma with reactive pleural effusion. A 58-year-old female presented with grade 4 dyspnea and dysphagia, with a mediastinal mass observed with on PET. CT-guided biopsy results were suggestive of IgG kappa-type EMP arising from the anterior mediastinum. The patient was treated with local radiotherapy to the mediastinum, and had clinical and radiological response $s$ were good. Radiotherapy is an effective treatment for mediastinal EMP, but a complete workup is mandatory, including PET, as the majority of such masses coexist with multiple myeloma. (Turk J Hematol 2011; 28: 228-31)
\end{abstract}

Key words: Extramedullary, plasmacytoma, mediastinal, radiotherapy

Received: August 26, $2010 \quad$ Accepted: January 12, 2011

Özet

Ekstramedüller plazmasitom (EMP) kemik iliği tutulumu veya multipl miyelomun diğer sistemik özelliklerinin bulunmadı̆̆ bir plazma hücre neoplazisidir. Özellikle mediasten kökenli EMP seyrek görüldügünden büyük ölçekli klinik çalışma sayısı oldukça azdır. Burada reaktif plevra sıvısı ile birlikte mediastende plazmasitomun görüldüğü nadir bir olgu bildirilmektedir. Derece 4 dispne ve disfajiden yakınan 58 yaşındaki bir kadında PET incelemesi mediasten kitlesini ortaya çıkarmıştır. CT-yönlendirmeli biyopsi bulguları ön mediastenden kaynaklanan IgG kappa-tip EMP tanısını koydurmuştur. Mediastene lokal radyoterapi uygulanarak iyi klinik ve radyolojik yant elde edilmiştir. Radyoterapi mediasten kökenli EMP için etkin bir tedavi olmakla birlikte. bu kitlelerin büyük bir bölümü multipl miyelomla birlikte geliştiğinden PET'i de içeren tam bir klinik çalışma yapmak zorunludur.

(Turk J Hematol 2011; 28: 228-31)

Anahtar kelimeler: Ekstramedüller plazmasitom, plazmasitom, mediastinal, radyoterapi

Geliş tarihi: 26 Ağustos 2010

Kabul tarihi: 12 Ocak 2011

Address for Correspondence: M.D. Ritu Bhutani, Rajiv Gandhi Cancer Institute and Research Centre, Department of Radiation Oncology, Sector V, Rohini 110085 Delhi, India Phone: 91-11-47022222 E-mail: bhutaniritu@gmail.com 


\section{Introduction}

Extramedullary plasmacytoma (EMP) is a plasma cell neoplasm involving soft tissues without any signs of systemic spread. It occurs in $<5 \%$ of cases and mediastinal presentation is. a rare presentation Herein we report a rare case of solitary mediastinal plasmacytoma and a review of the literature.

\section{Case presentation}

A 58-year-old female presented with upper chest swelling associated with grade 4 dyspnea and difficulty swallowing. Physical examination showed a $4 \times 3$-cm supraclavicular mass with diffuse borders and a $5 \times 5$-cm infraclavicular bulge fixed to underly-

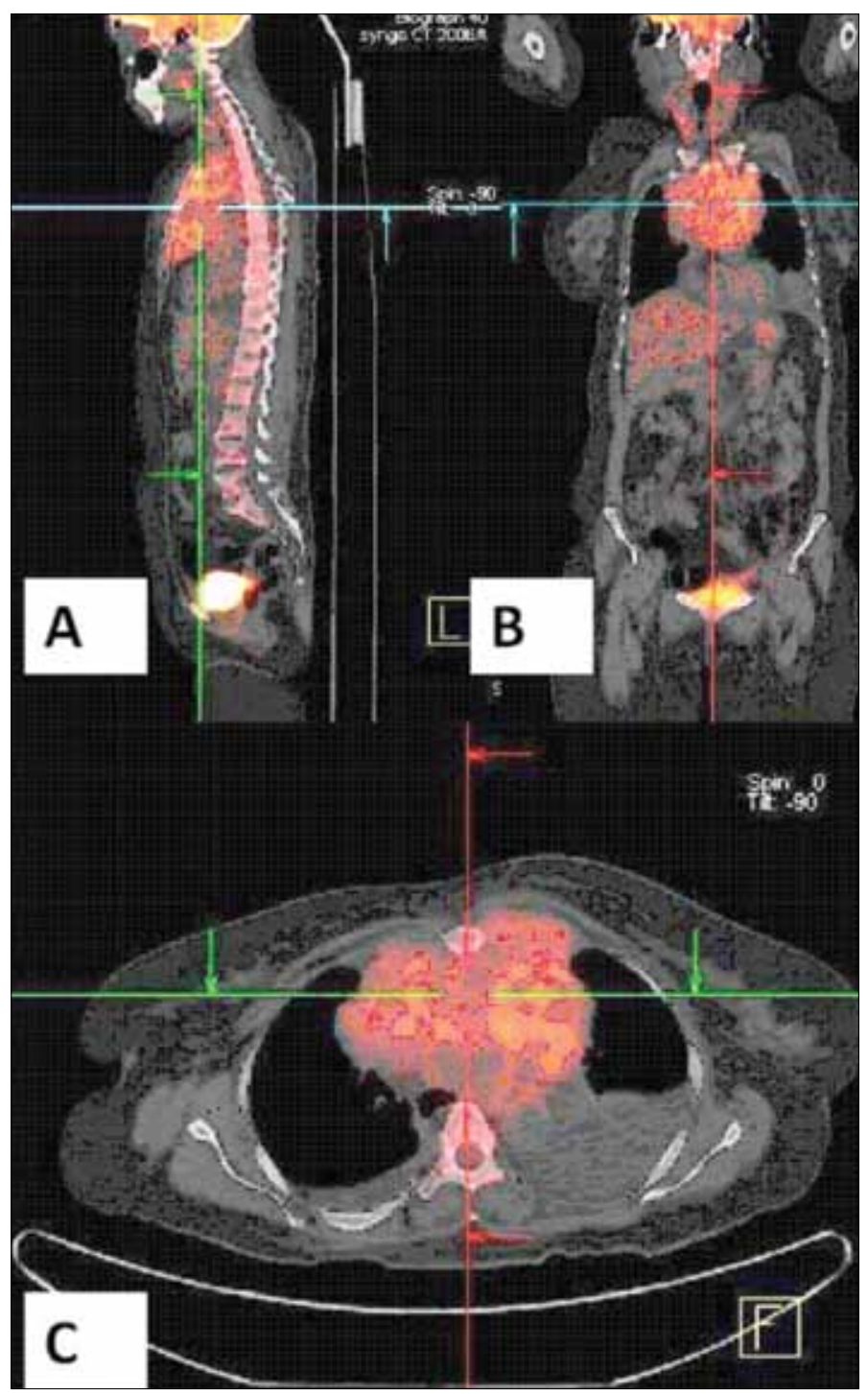

Figure 1. PET/CT shows a $10.3 \times 8.2-\mathrm{cm}$ anterior mediastinal mass (SUV: 2.6), with bilateral pleural effusion and collapse of the left lung. Saggital (A), coronal (B), and axial (C) views ing structures. Her breathing sounds were slightly coarse, without rales or rhonchi on auscultation. She was treated in the intensive care unit due to her inability to maintain oxygen saturation. PET CT showed an anterior mediastinal mass $(10.3 \times 8.2 \mathrm{~cm})$ extending up to the left supraclavicular region (Figure 1). The mass was abutting the major mediastinal vessels, overlying the manubrium sterni and chest wall, and was associated with bilateral pleural effusion. Cranial, spinal, and pelvic X-ray showed that there weren't any osteolytic regions. Light microscopic examination showed scattered oval cells with eccentric nuclei and abundant eosinophilic cytoplasm suggestive of plasmacytoma. The plasma cells stained positive with LCA, CD138, and reduced kappa light-chain concentrations (Figure 2). Bone marrow biopsy results showed normal patterns of cell distribution. Pleural fluid cytological examination showed lymphocytes and reactive mesothelial cells. Serum calcium was normal and urine was negative for Bence Jones proteins. Serum electrophoresis showed an $\mathrm{M}$ spike in the gamma globulin (IgG kappa) region with a value of $3.07 \mathrm{~g} / \mathrm{dL}$. Based on these findings, the patient was diagnosed as mediastinal plasmacytoma. The patient received 3-dimensional conformal external beam radiotherapy (3D-CRT) to the mediastinum ( $46.2 \mathrm{~Gy}$ in 26 fractions). Gross target volume GTV was contoured under FDG-PET guidance with margins based on our institutional protocol. The treatment was

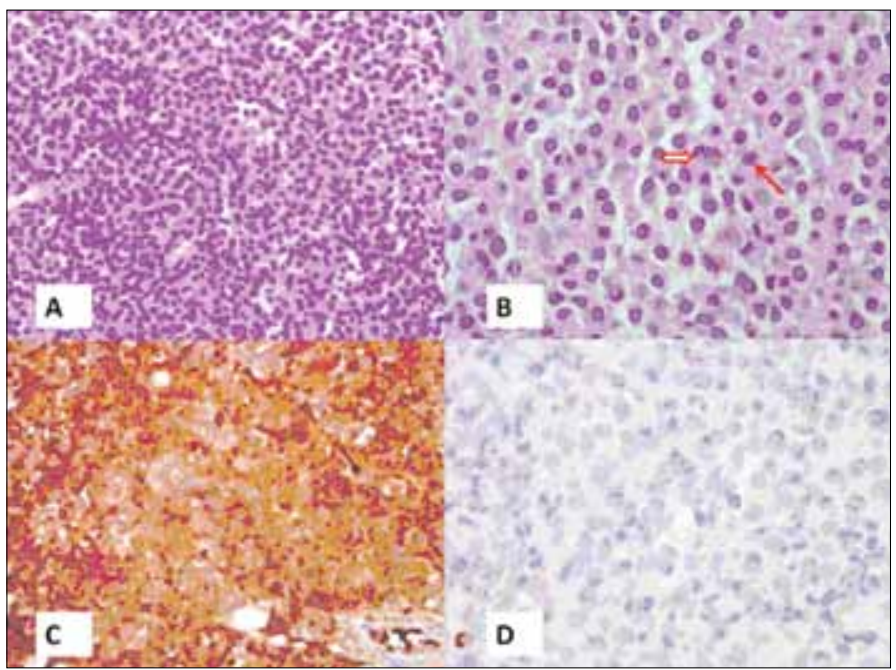

Figure 2. Microscopic examination. A. Diffuse sheets of plasma cells $(\mathrm{H} \& \mathrm{E}, 100 \times)$. B. Plasma cells show abundant eosinophilic cytoplasm, eccentric cartwheel nuclei with mitosis (thick arrow), and para nuclear halos (thin arrow) (H\&E, 200×). C and D. Tumor cells show kappa light chain restriction (C), but no lambda restriction (D) $(\mathrm{DAB}, 200 \times)$ 
planned using a PLATO 2.7.7 system and was administered under imaging guidance. Clinical improvement was evident after 2 weeks of treatment, as the patients was weaned from oxygen, and able to walk and swallow liquids, and at the end of the treatment an excellent radiological response was noted. At the time this report was written, the patient was receiving adjuvant chemotherapy. We had taken a written informed consent from the patient. We have ethical committee approval.

\section{Discussion}

EMP is a soft tissue plasma cell tumor occurring in the absence of systemic signs of multiple myeloma, such as a bone osteolytic lesion, plasma cell infiltration in bone marrow, a lytic bone lesion, and serum or urine myeloma proteins [1]. A historical review [2] of 700 patients showed that there was head and neck involvement in 80\%-90\%, especially in the aerodigestive tract. Case reports of involvement of the liver, pancreas, lungs, skin, and thyroid gland do exist. It is most unusual for this tumor to present in the mediastinum as a primary solitary lesion. To date, only 12 cases of EMP involving the mediastinum have been reported in the English language literature; mean age at presentation was 55 years. Presentation (Table 1) included a mediastinum mass associated with intralobar effusion [3], pulmonary nodules [4], multiple myeloma [5,6], and mimicking hemangioma [7]; however, the presented case is unusual, as it involved a solitary anterior mediastinal mass that presented with grade 4 dyspnea, and responded quickly during the course of treatment. The plasmacytoma in the presented case was aggressive, which was evident by increased contrast uptake observed with PET, in contrast to the lack of increased uptake in indolent plasmacytoma. The presented case also highlights the clinical usefulness of PET/CT in imaging plasmacytomas, as suggested by Masood et al. [5]. Pathologically proven pleural effusion is an occasional finding in patients with multiple myeloma, which occurs in approximately $6 \%$ of patients [8]. The cause of pleural effusion in the presented case was not clear and as it was reactive, lymphatic drainage obstruction caused by the mediastinal mass might have been responsible.

Plasma cell neoplasms are relatively sensitive to radiotherapy; however, a review of the literature by Alexiou et al. [2] reported that combined therapy (surgery and radiotherapy) results in better overall and recurrence-free survival $(p=0.027)$. Nonetheless, these results span the greater part of a century (19051997) and radiotherapy techniques have changed

Table 1. Published reports of mediastinal mass

\begin{tabular}{|c|c|c|c|c|}
\hline Serial no & Author & Presentation & Treatment & Follow-up \\
\hline 1 & Divis and Sikl (1928) & Anterior mediastinum & Resection & Alive at 3 months \\
\hline 2 & Bross (1931) & Posterior mediastinum & Resection & Necropsy report \\
\hline 3 & Snapper (1953) & Mediastinum and lung with MM & Radiotherapy & Necropsy report \\
\hline 4 & Niwal (1987) & Superior mediastinum & - & - \\
\hline 7 & Ahmed (2000) & Posterior mediastinum & Surgery & Nor available \\
\hline 8 & Nandekar (2000) & $\begin{array}{l}\text { Middle mediastinum mimics } \\
\text { hemangioma with MM }\end{array}$ & Chemotherapy & Alive at 2 years \\
\hline 11 & Ashiq (2008) & Posterior mediastinum with MM & Chemotherapy & Not available \\
\hline 12 & Hyemin (2010) & $\begin{array}{l}\text { Anterior mediastinum + pleural nodules } \\
+ \text { pleural effusions with MM }\end{array}$ & Chemotherapy & Not available \\
\hline
\end{tabular}


during that time. Currently, radiotherapy is the treatment of choice for solitary plasmacytoma and the dose of 40-50 Gy (depending on tumor size) is delivered over 4-6 weeks. It is associated with a $<5 \%$ risk of local recurrence and most carefully staged patients with solitary EMP can be cured $[9,10]$. There is no published evidence for the role of adjuvant chemotherapy in the treatment of solitary extramedullary plasmacytoma Tsang et al. [11] and Holland et al. [12] suggest that tumours $>5 \mathrm{~cm}$ are associated with a high risk of failure, which was a rationale for proposing chemotherapy to the presented patient.

Though $5 \%$ of patients have coexistent multiple myeloma [11], our literature review suggests 30\% involvement in mediastinal EMP. This indicates that plasmacytoma involving the mediastinum provides an early hint to the diagnosis of occult multiple myeloma and should be included in the differential diagnosis of mediastinal masses. Thusly, after the diagnosis of plasmacytoma, aggressive investigation for multiple myeloma is vital, as such patients can be candidates for adjuvant chemotherapy.

\section{Conflict of interest statement}

The authors of this paper have no conflicts of interest, including specific financial interests, relationships, and/or affiliations relevant to the subject matter or materials included.

\section{References}

1. Soesan M, Paccagnella A, Chiarion-Sileni V, Salvagno L, Fornasiero A,Sotti G, Zorat P-L, Favaretto A, Fiorentino M. Extramedullary plasmacytoma: Clinical behaviour and response to treatment. Ann Oncol 1992;3:51-7.
2. Alexiou C, Kau RJ, Dietzfelbinger H, Kremer M, Spiess JC, SchratzenstallerB, Arnold W. Extra medullary plasmacytoma: tumor occurrence and therapeutic concepts. Cancer 1999;85:2305-14.

3. Ji Hye Min, Tae Sung Kim, Young-Hyeh Ko, Ki-Hyun Kim. A Case of Mediastinal Extramedullary Plasmacytoma associated with multiple myeloma. J Korean Soc Radiol 2010;62:365-8.

4. Herskovic T, Andersen HA, Bayrd ED. Intrathoratic plasmacytomas: Presentation of 21 cases and review of literature. Dis Chest 1965;47:1.

5. Masood A, Hudhud KH, Hegazi A, Syed G. Mediastinal plasmacytoma with multiple myeloma presenting as a diagnostic dilemma..Cases J. 2008;21:116.

6. Moran CA, Suster S, Fishback NF, Koss MN. Extramedullary plasmacytomas presenting as mediastinal masses: clinicopathologic study of two cases preceding the onset of multiple myeloma..Mod Pathol 1995;8:257.

7. Nandedkar MA, Abbondanzo SL, Miettinen M. Extramedullary manifestation of multiple myeloma (systemic plasmacytoma) that simulates hemangioma. Arch Pathol Lab Med 2000;124:628-31.

8. Pacheco A, Perpiñá A, Escribano L, Sanz I, Bellas C. Pleural effusion as first sign of extramedullary plasmacytoma.Chest. 1992;102:296-7.

9. Liebross RH, Ha CS, Cox JD,. Solitary bone plasmacytoma: outcome and prognostic factors following radiotherapy. Int J Radiat Oncol Biol Phys 1998;41:1063-7.

10. Liebross RH, Ha CS, Cox JD. Clinical course of solitary extramedullary plasmacytoma. Radiother Oncol. Sep 1999;52:245-9.

11. Tsang, R.W., Gospodarowicz, M.K., Pintilie, M., Bezjak, A., Wells, W.,Hodgson, D.C. \& Stewart.Solitary plasmacytoma treated with radiotherapy: impact of tumour size on outcome. International Journal of Radiation Oncology, Biology, Physics 2001;50,113-20.

12. Holland J, Trenkner DA, Wasserman TH, Fineberg B. Plasmacytoma. Treatment results and conversion to myeloma.Cancer. 1992;15;69:1513-7. 